\title{
ARTICLE OPEN \\ Corrosion resistance of MCrAlX coatings in a molten chloride for thermal storage in concentrating solar power applications
}

\author{
Judith C. Gomez-Vidal (iD)
}

Corrosion evaluations of Incoloy $800 \mathrm{H}(\mathrm{In} 800 \mathrm{H})$ and stainless steel AISI 310 (310SS), in bare and coated conditions, were performed in $34.42 \mathrm{wt} \% \mathrm{NaCl}-55.47 \mathrm{wt} \% \mathrm{KCl}$ at $700{ }^{\circ} \mathrm{C}$ in a nitrogen atmosphere. This $\mathrm{NaCl}-\mathrm{KCl}$ composition has a melting point of $657^{\circ} \mathrm{C}$, which makes it suitable for latent-heat thermal energy storage in concentrating solar power applications. Several nickel-based MCrAIX coatings were tested, where $\mathrm{M}=\mathrm{Ni}$ and/or $\mathrm{Co}$ and $\mathrm{X}=\mathrm{Y}, \mathrm{Ta}, \mathrm{Hf}$, and/or Si. Electrochemical testing was carried out to determine corrosion rates. The bare $\mathrm{In} 800 \mathrm{H}$ and $310 \mathrm{SS}$ alloys corroded rapidly $(\sim 2500$ and $4500 \mu \mathrm{m} / \mathrm{yr}$, respectively, assuming uniform corrosion). Concentrating solar power plants need containment materials with a lifetime of at least 30 years; thus, these corrosion rates are excessive. Corrosion mitigation approaches are being investigated to obtain degradation on the order of $20 \mu \mathrm{m} /$ yr or lower. The lowest corrosion rate of $190 \mu \mathrm{m} / \mathrm{yr}$ was obtained for atmospheric plasma spray NiCoCrAlY coatings pre-oxidized in air at $900{ }^{\circ} \mathrm{C}$ for $24 \mathrm{~h}$ with a heating/cooling rate of $0.5^{\circ} \mathrm{C} / \mathrm{min}$. Metallographic characterization of the corroded surfaces showed that the formation of a uniform thin alumina scale before exposure to the molten chloride system considerably reduced the corrosion of the alloy. However, the rates of corrosion determined herein are considerable, highlighting the relevance of testing materials durability in solar power applications.

npj Materials Degradation (2017)1:7; doi:10.1038/s41529-017-0012-3

\section{INTRODUCTION}

Next-generation solar power conversion systems in concentrating solar power (CSP) applications require high-temperature advanced fluids in the range of $550-750^{\circ} \mathrm{C}$ to make solar electricity costcompetitive with power from conventional generation technologies. ${ }^{1}$ CSP technology captures and stores the sun's energy in the form of heat. With the advantage of having thermal energy storage (TES), CSP can deliver renewable energy while providing important capacity, reliability, and stability attributes to the electrical grid. Current state-of-the-art CSP plants deliver thermal energy up to $565^{\circ} \mathrm{C}$ using nitrate salts as the heat-transfer fluid (HTF) and TES material. Because these salts are unstable at temperatures above $600^{\circ} \mathrm{C}$, other salt chemistries must be investigated. Molten chlorides are being considered as candidates for advanced high-temperature CSP applications because of their low cost, high decomposition temperatures, and good thermal properties. ${ }^{2}$ Molten chloride salts could be used as the HTF in solar receivers and/or as sensible or latent TES material. However, in general, they are corrosive to common alloys used in CSP thermal components, e.g., heat exchangers, piping, and storage vessels at these high temperatures. We are investigating corrosion in molten salts at high temperatures for solar applications and its mitigation to obtain degradation of containment materials around $20 \mu \mathrm{m} / \mathrm{yr}$ or lower, thus providing a lifetime for CSP plants of 30 years or more. $^{3-9}$

Corrosion behavior of steel containers in latent TES molten eutectic $\mathrm{KCl}-\mathrm{LiCl}$ from 310 to $420^{\circ} \mathrm{C}$ in air and argon has been evaluated with the long-term weight-loss technique for up to $4000 \mathrm{~h}$ of immersion. The effect of water and other impurities in the salt were also studied, with pitting corrosion detected and the addition of $2 \mathrm{wt} \% \mathrm{H}_{2} \mathrm{O}$ causing a severe increase in corrosion in these environments. ${ }^{10}$ Mechanical failure of components due to localized corrosion is catastrophic because the failure is usually rapid and unexpected. Uniform corrosion, in which the surface gradually degrades, is preferred because it is simpler to detect, predict, and often, to control.

Weight-loss corrosion techniques are accurate but time intensive. To obtain corrosion rates, $>500 \mathrm{~h}$ of immersion time is usually required. ${ }^{11}$ The use of electrochemical techniques allows the evaluation of continuous corrosion, and the determination of instantaneous corrosion rates, corrosion mechanisms, and process-controlling steps after only a few hours of testing, such as the tests reported herein.

The type of corrosion typical of chromia-forming alloys in molten chlorides is localized, such as intergranular and pitting corrosion. ${ }^{11}$ It has been observed that $\mathrm{Cr}$ is commonly depleted near the regions of dissolution. The corrosion mechanism being proposed elsewhere is that $\mathrm{CrCl}_{3}$ will form at the bottom of the pits or degraded grain boundaries, and it will rapidly diffuse toward the alloy surface. At the fluid/alloy interface, dissolved oxygen is higher in content than at the bottom of the pits. Because of the higher oxygen potential, $\mathrm{CrCl}_{3}$ is oxidized to nonprotective and non-adherent $\mathrm{Cr}_{2} \mathrm{O}_{3}$ and chlorine is liberated, so the degradation process continues by forming more $\mathrm{CrCl}_{3}{ }^{12}$ Chromium can cause deterioration of the corrosion resistance in chloride molten salts exposed to oxidizing atmospheres by forming chromates and chromium chlorides that are oxidants and can increase corrosion. ${ }^{13}$

Several alloys have been tested in molten chlorides systems for high-temperature solar thermal applications. ${ }^{3-7}$ Stainless steels AISI 347 (347SS) and AISI 310 (310SS), Incoloy $800 \mathrm{H}$ (In800H), and

\footnotetext{
${ }^{1}$ National Renewable Energy Laboratory, 15013 Denver West Parkway, Golden, CO 80401, USA
}

Correspondence: Judith C. Gomez-Vidal (judith.vidal@nrel.gov)

Received: 24 February 2017 Revised: 1 June 2017 Accepted: 10 July 2017

Published online: 18 September 2017 
Inconel 625 (IN625) were tested in molten eutectic $34.42 \mathrm{wt} \% \mathrm{NaCl}$ $-65.58 \mathrm{wt} \% \mathrm{LiCl}$ at 650 and $700{ }^{\circ} \mathrm{C}$ in nitrogen atmosphere. ${ }^{3}$ At $650^{\circ} \mathrm{C}$, the lowest corrosion rate of $2800 \pm 380 \mu \mathrm{m} / \mathrm{yr}$ was obtained for IN625. Less expensive alloys such as 310 SS and In $800 \mathrm{H}$ had corrosion rates of $6420 \pm 400 \mu \mathrm{m} / \mathrm{yr}$ and $5940 \pm 330$ $\mu \mathrm{m} / \mathrm{yr}$, respectively. At $700^{\circ} \mathrm{C}$, their corrosion rates increased to $12,450 \pm 1520 \mu \mathrm{m} / \mathrm{yr}$ and $14310 \pm 1360 \mu \mathrm{m} / \mathrm{yr}$ for each alloy, respectively. These two alloys are of special interest for solar thermal applications because of their high mechanical resistance and low cost; but their corrosion in molten chlorides must be mitigated and controlled.

Coatings have been used to protect high-temperature gas turbines for several decades. These turbine blades, made of nickel superalloys, reach temperatures above $1000^{\circ} \mathrm{C}$ and are exposed to thin-film molten-salt corrosion. Coatings such as MCrAIX ( $\mathrm{M}=\mathrm{Ni}$ and/or $\mathrm{Co} ; \mathrm{X}=\mathrm{Y}, \mathrm{Hf}, \mathrm{Si}$, and/or $\mathrm{Ta}$ ) have been extensively studied to protect nickel superalloys from molten-salt environments containing chlorides, sulfates, vanadates, and more. ${ }^{14-34}$ These coatings rely on the formation of dense and adherent alumina and chromia to provide high-temperature corrosion resistance against molten salts. Low aluminum content in MCrAIXs-between 5 and $12 \mathrm{wt} \%$-is required to achieve a good balance between mechanical properties and high-temperature performance. ${ }^{18,} 19,29$ Aluminum-containing coatings have proven to be effective against molten-salt corrosion because of alumina formation. The presence of this oxide in oxidized $\beta$-NiAIDy coatings provided protection against an environment containing $\mathrm{NaCl}-\mathrm{MgCl}_{2}-\mathrm{KCl}-\mathrm{CaCl}_{2}$ at $950^{\circ} \mathrm{C}^{34}$

Research in turbine-blade technology has reported that the oxidation of aluminum is self-limiting and that high to medium concentrations of chromium are required to help in forming the thicker protective a-alumina films on top of pre-oxidized coatings. $^{35,} 36$ Several dry and wet atmospheres have been tested at different temperature ranges to study the kinetics, composition, and morphology of the alumina films produced by oxidation. ${ }^{37-40}$ Chromium is considered a protective alumina-scale former. The substitution of greater than $8-10$ at $\% \mathrm{Cr}$ reduces the level of $\mathrm{Al}$ needed for protective alumina-scale formation during oxidation at $1000^{\circ} \mathrm{C}$. Protective alumina formation refers to establishing a continuous $\mathrm{a}-\mathrm{Al}_{2} \mathrm{O}_{3}$ scale over most of the sample surface. ${ }^{35}$ The formation of $\mathrm{a}-\mathrm{Al}_{2} \mathrm{O}_{3}$ has been studied over the past several decades, from which the phase-transformation path was determined to be the following: amorphous $\rightarrow \gamma \rightarrow \delta \rightarrow \theta \rightarrow a-\mathrm{Al}_{2} \mathrm{O}_{3}{ }^{41}$ The amorphous, $\gamma, \delta$, and $\theta$ forms of alumina are fast growing, more voluminous, more porous, and less protective than $\mathrm{a}-\mathrm{Al}_{2} \mathrm{O}_{3}$. According to this transformation route, temperatures higher than $1000^{\circ} \mathrm{C}$, which weaken the mechanical properties of the substrate materials, are essential to obtain $\mathrm{a}-\mathrm{Al}_{2} \mathrm{O}_{3}$. However, the formation temperature of $\mathrm{a}-\mathrm{Al}_{2} \mathrm{O}_{3}$ can decrease to $900{ }^{\circ} \mathrm{C}$ in alloys containing $\mathrm{Cr}^{42} \mathrm{Cr}_{2} \mathrm{O}_{3}$ forms first and it immediately acts as a nucleus for a$\mathrm{Al}_{2} \mathrm{O}_{3}$ to form at the $\mathrm{Cr}_{2} \mathrm{O}_{3}$ /alloy interface. Pre-oxidation treatment on Fe-Al- $\mathrm{Cr}$ alloys air heated for $10 \mathrm{~h}$ at $900^{\circ} \mathrm{C}$ formed a dense and continuous alumina scale. ${ }^{13,43}$

Corrosion of alloys and coatings in molten salts has been evaluated using electrochemical techniques such as open-circuit potential (OCP) followed by potentiodynamic polarization. ${ }^{42}$ When metallic alloys are immersed in ionic fluids, such as molten salts, electrochemical reactions are possible, and under no external potential applied, the OCP is establish. Because of the complexity of molten salts, a dynamic pseudo-equilibrium is established at the fluid/metal interface. To determine a so-called steady-state $\mathrm{OCP}$, potentials are recorded as a function of time until stability is reached, which is usually for $\mathrm{dE} / \mathrm{dt} \leq 100 \mu \mathrm{V} / \mathrm{s}^{12,44-47}$

The metallic area exposed to the molten salt is used to determine the current density (i) in $\mathrm{A} / \mathrm{cm}^{2}$, as a result of cathodic $(\mathrm{E}<\mathrm{OCP})$ and anodic $(\mathrm{E}>\mathrm{OCP})$ polarization. ${ }^{47}$ The corrosion current density $\left(i_{\text {corr }}\right)$ and corrosion potential $\left(E_{\text {corr }}\right)$ were determined from Tafel extrapolation. The corrosion rate $(C R)$ can be estimated through the Faraday Law ${ }^{46,47}$ if one assumes general corrosion:

$$
C R=\frac{i_{\text {corr }} \cdot K}{\text { palloy } \cdot \sum\left(\frac{f_{i} \cdot n_{i}}{M W_{i}}\right)},
$$

where $K$ is a correlation constant that defines the units of $C R$ $\left(3.272 \times 10^{6}\right.$ for $C R$ in $\left.\mu \mathrm{m} / \mathrm{yr}\right), \rho_{\text {alloy }}$ is the alloy density $\left(\mathrm{g} / \mathrm{cm}^{3}\right), f_{i}$ is the molar fraction of element $i$ in the alloy, $n_{i}$ is the number of electrons being transferred in element $i$, and $M W_{i}$ is the atomic weight of element $i$.

The current investigation was intended to determine the ability of thermal-sprayed MCrAIX coatings to protect less expensive alloys from corrosion in molten chloride environments.

\section{RESULTS AND DISCUSSION}

Corrosion behavior of bare alloys and coatings

The potentiodynamic polarization curves of corroded bare alloys and coatings showed a current-density limit (near vertical line at high overpotentials) in which the current remains constant while the potential increases (Supplementary Figure 1). This limiting current density occurs when the electrode process is controlled by mass transfer.

Coating Amdry 510-NiCrAl (Supplementary Fig. 1a) in the asdeposited condition, during the first polarization, shows the following: in the anodic polarization branch, the current tends to decrease or remains stable, whereas the applied potential increases to more positive values. This behavior is common in alloys that are able to passivate due to the formation of a protective layer. Because of this trend, a second polarization was immediately performed, obtaining a corrosion rate almost an order of magnitude lower than the as-deposited test $(590 \mu \mathrm{m} / \mathrm{yr}$ vs $3340 \mu \mathrm{m} / \mathrm{yr}$ ). Two other samples of Amdry 510 were oxidized under air at 800 and $900{ }^{\circ} \mathrm{C}$ using a $0.5^{\circ} \mathrm{C} / \mathrm{min}$ heating/cooling rate before being immersed in the molten salt. The corrosion rate decreased to similar values (700 and $450 \mu \mathrm{m} / \mathrm{yr}$ for samples preoxidized at 800 and $900^{\circ} \mathrm{C}$, respectively) as the one obtained with the second polarization. The decrease in the corrosion rate is likely associated with the formation of protective oxide scales that act as barriers, separating the metal substrate from the corrosive environment. This is a common behavior of alloys that can passivate by forming protective scales.

Active corrosion, represented by a continuous increase in current density in the electron-transfer control region, was observed in the bare alloys (310SS and In800H) and the other tested coatings Amdry 997-NiCoCrAIYTa, Diamalloy 4700-NiCoCrAl, Diamalloy 4008NS-NiAl, and SPM4-6667-NiCoCrAIYHfSi (see Supplementary Fig. $1 \mathrm{a}, 1 \mathrm{~b}, 1 \mathrm{c}$, and $1 \mathrm{~d}$, respectively). Most of the coatings after oxidation have a more positive $E_{\text {corr }}$ compared with the as-deposited condition. By moving to more positive potential, the sample is going toward a less active corrosion region.

By using the intersection of the cathodic and anodic Tafel lines and Eq. 1, corrosion rates were determined for each sample and pre-oxidation condition. Corrosion results of bare substrates and coatings in eutectic $\mathrm{NaCl}-\mathrm{KCl}$ at $700{ }^{\circ} \mathrm{C}$ in $\mathrm{N}_{2}(\mathrm{~g})$ are shown in Table 1. Different temperatures $\left(800,900\right.$, and $\left.1000^{\circ} \mathrm{C}\right)$ and dwelling times $(4,20$, and $24 \mathrm{~h}$ ) were used during pre-oxidation to determine the conditions in which protective scales, such as alumina and chromia, were able to form. It has been reported that protective a-alumina grows at temperatures around $900^{\circ} \mathrm{C}$ if long periods of times are allowed. The lowest dwelling time of $4 \mathrm{~h}$ was used only at $1000{ }^{\circ} \mathrm{C}$ based on previous tests. ${ }^{4,5}$ These temperatures and times were selected following energy cost considerations if preoxidation of alloys is used to protect the alloys from corrosion in molten salts at commercial scale.

It is clear that the corrosion is mitigated by coating $310 \mathrm{SS}$ and In $800 \mathrm{H}$. The corrosion rate decreased one order of magnitude 
after the coating deposition. Further pre-oxidation of the coatings allowed the corrosion rate to decrease to even lower values. Different oxidation temperatures were evaluated to determine the best and more protective condition that provides the lower corrosion rate when exposed to molten chlorides.

Coating HVOF-NiCoCrAlYTa pre-oxidized at $1000^{\circ} \mathrm{C}$ corroded at a rate much higher than at the as-deposited condition. The oxidation temperature was close to the maximum operating temperature $\left(1050^{\circ} \mathrm{C}\right)$ of the coating at which the raw material supplier claims that loss of adhesion could occur. On the other hand, it is possible that the pre-oxidation time of $4 \mathrm{~h}$ was not enough to develop a uniform and dense layer of the protective oxide at the surface.

The lowest corrosion rate of $190 \mu \mathrm{m} / \mathrm{yr}$ was obtained for HVOF-NiCoCrAlYTa pre-oxidized in air at $900^{\circ} \mathrm{C}$ for $24 \mathrm{~h}$. By

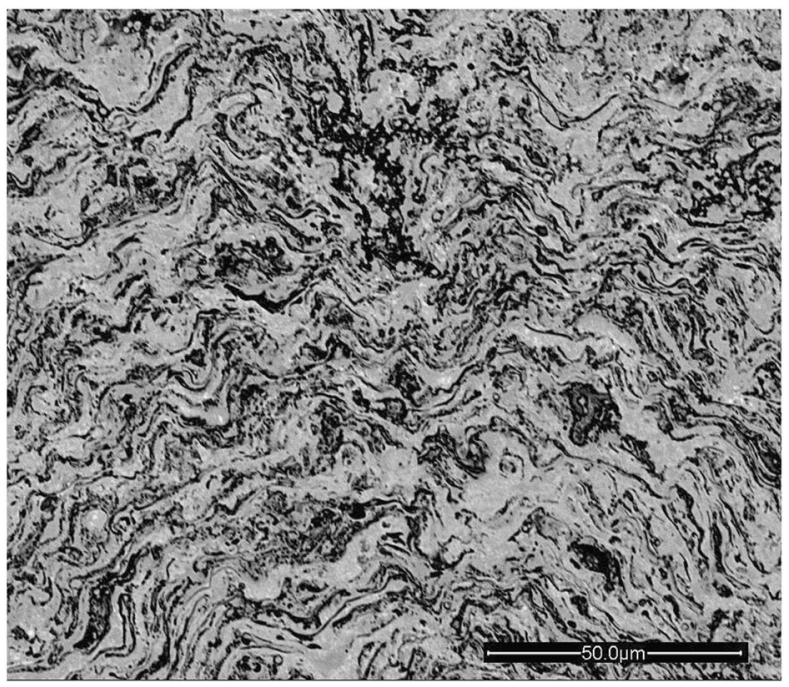

Fig. 1 BSE-SEM image of coating microstructure of oxidized HVOF-NiCoCrAIYTa (air, $900^{\circ} \mathrm{C}, 24 \mathrm{~h}, 0.5^{\circ} \mathrm{C} / \mathrm{min}$ ) away from the top surface and interface with steel. Scale bar is $50 \mu \mathrm{m}$ depositing and oxidizing this coating, the corrosion of $310 \mathrm{SS}$ $(\sim 4600 \mu \mathrm{m} / \mathrm{yr})$ was reduced by $96 \%$. Similar results were obtained in pre-oxidized alumina-forming alloys exposed to molten eutectic $\mathrm{MgCl}_{2}-\mathrm{KCl}$ at $700{ }^{\circ} \mathrm{C}$ in a flowing $\mathrm{Ar}$ atmosphere. ${ }^{4,5,8}$

Qualitative adhesion tests of the best-performing coating over $310 \mathrm{SS}$ and $\ln 800 \mathrm{H}$ after oxidation were performed using standard ASTM 3359. A diamond saw was used to cut through the coating, creating a grid with $2-3-\mathrm{mm}$ spacing. The coatings remained very well adhered to the substrate given that the adhesion test did not remove any coating material.

Microstructure of coatings and substrate alloys before and after degradation

The HVOF-NiCoCrAIYTa coating in the as-deposited condition was metallographically prepared and characterized. The light microscopy (LM) micrograph of the coating oxidized in air at 900 and $5^{\circ} \mathrm{C} / \mathrm{min}$ (as the heating and cooling rates) shows fissures or cracks in the coating at the top of the specimen (Supplementary Fig. 2). It is possible that they are produced by thermal stresses during heating and/or cooling. Because of this, further oxidation treatments were performed using lower heating/cooling rates $\left(0.5^{\circ} \mathrm{C} / \mathrm{min}\right)$.

Backscattered-electron in scanning electron microscope (BSESEM) imaging of as-deposited HVOF-NiCoCrAIYTa reveals a coating microstructure characterized by a multiphase dark "wavy" or "swirled" constituent in a light-contrasted matrix (Supplementary Figs. 3 and 4). This microstructure is consistent with those observed for thermally sprayed coatings in which liquid metal droplets are sprayed onto a substrate. ${ }^{48}$ The droplets are deformed on impact and generally possess oxidized surfaces. The dark wavy morphology has been associated with remnant oxide scales of the droplets and indicates the severe deformation that droplets undergo during deposition. The coating/steel interface at the top of the specimen appears to undulate gently; but for the most part, it is well bonded. Bonding appears to be associated with interface undulation (Supplementary Fig. 4a).

The microstructure of the etched condition of as-deposited HVOF-NiCoCrAlYTa shows a central band of finer grains (Supplementary Fig. 4a) and a deformed and partially recrystallized layer

Table 1. Open circuit potential (OCP), corrosion current density and corrosion rates of bare alloys and coatings in $44.53 \mathrm{wt} \% \mathrm{NaCl}-55.47 \mathrm{wt} \% \mathrm{KCl}$ at $700{ }^{\circ} \mathrm{C}$ in $\mathrm{N}_{2}(\mathrm{~g})$ atmosphere

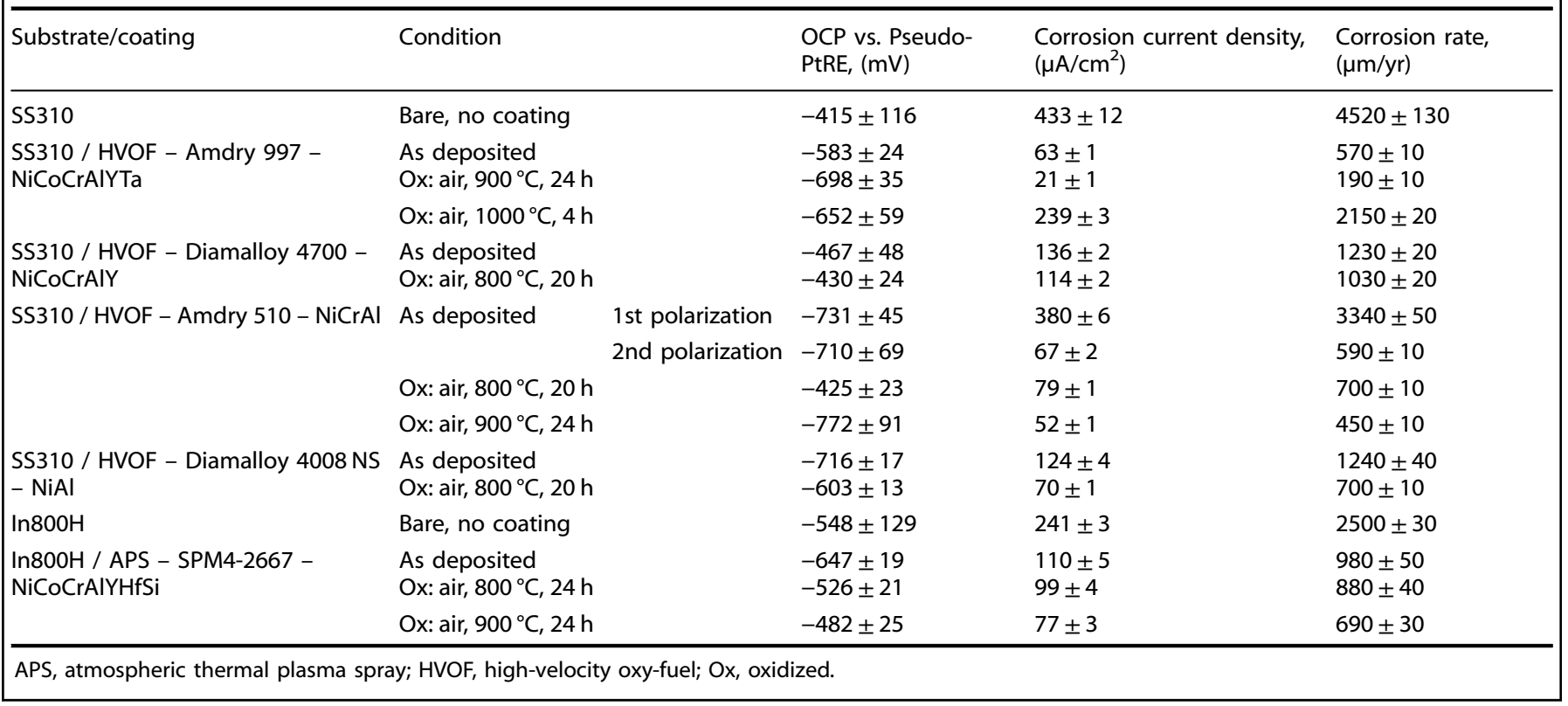


at the coating/steel interface (Supplementary Fig. 4b) typical of thermal sprayed samples were obtained. Before the coating deposition, the alloy is prepared using sand blasting to remove oxides and to undulate the surface to improve the coating adhesion. The stainless steel of the substrate is partially sensitized due to partial ditching of boundaries revealed with electroetching (see Supplementary Fig. 4c).

BSE-SEM imaging of oxidized HVOF-NiCoCrAIYTa (air, $900{ }^{\circ} \mathrm{C}, 24$ $\mathrm{h}, 0.5^{\circ} \mathrm{C} / \mathrm{min}$ ) is shown in Fig. 1 . The coating comprises a finely divided mixture of dark-contrasted "swirly" phase in a lightcontrasted matrix. The semi-quantitative chemical analysis via energy-dispersive X-ray spectrometry (EDS) of the overall microstructure, as well as the light and dark phases revealed that the coating is substantially $\mathrm{Ni}, \mathrm{Co}, \mathrm{Cr}, \mathrm{Al}$, and $\mathrm{Y}$ with some $\mathrm{O}$ (Supplementary Table 1). The light-contrasted matrix is similar to the overall coating composition, whereas the swirly dark phase is higher in $\mathrm{Al}$ and $\mathrm{O}$, presumably alumina.

BSE-FESEM/EDS analysis of oxidized HVOF-NiCoCrAIYTa (air, $900^{\circ} \mathrm{C}, 24 \mathrm{~h}, 0.5^{\circ} \mathrm{C} / \mathrm{min}$ ) is shown in Fig. 2. At the top surface of the coating, a thin, continuous, and uniform darker layer with a thickness between 1.5 and $4 \mu \mathrm{m}$ is observed. Consistent with its darker BSE contrast and the EDS punctual analysis (Fig. 2a), the dark layer is generally enriched in $\mathrm{O}$, suggesting an oxide scale. $\mathrm{Cr}$ and $\mathrm{Al}$ where resolved, but it should be noted that individual analyses may be confounded by overlap of the X-ray interaction volume of the SEM electron beam. From the EDS line scan (Fig. 2b) and maps (Fig. 2c), it is clear that the dark surface layer is an Al oxide that seems to cover the whole surface of the coating.

The oxidized HVOF-NiCoCrAlYTa (air, $900^{\circ} \mathrm{C}, 24 \mathrm{~h}, 0.5^{\circ} \mathrm{C} / \mathrm{min}$ ) cross-section specimen was electroetched in an aqueous $10 \%$ oxalic acid electrolyte to characterize the microstructure of the substrate. The microstructure of the 310 SS substrate (Supplementary Fig. 5) reveals heavy and continuous etching or "ditching" of the grains and twin boundaries and deformation bands. Boundary ditching generally occurs because the microstructure has been sensitized by precipitation of $\mathrm{Cr}$-rich carbides at the boundary. Sensitization occurs because this precipitation leaves the steel matrix locally depleted in $\mathrm{Cr}$ in areas near the grain boundaries. This sensitized condition has been reported to likely produce intergranular corrosion in aqueous acid solutions. ${ }^{49,} 50$

Sensitization is likely with relatively high $C$ levels in the steel and a sufficiently long time in the temperature range of $700-900^{\circ} \mathrm{C}$. A long time can also be associated with slow cooling in the same temperature range. $310 \mathrm{SS}$ has a relatively high maximum carbon content of $0.25 \mathrm{wt} \%$, compared with other 300 -series stainless steels.

Fine-scale microstructural features have been produced in the immediate vicinity of the coating/steel interface (Supplementary Fig. 5b). Fine-scale microstructure at the interface is associated with a layer of localized deformation that has apparently undergone recrystallization to produce a layer of very fine grains and some grain growth immediately at the interface. The deformation in the vicinity of the interface was produced by sand-blasting pre-treatment of $310 \mathrm{SS}$ required to facilitate coating adhesion. The fine recrystallized grain structure at the interface appears to have been facilitated by precipitate pinning of grain boundaries. The oxalic acid electroetching of In800H also revealed a sensitized microstructure in this alloy (Supplementary Fig. 6). The grain boundaries of an equiaxed grain structure, as well as an intragranular deformation structure of slip lines and deformation bands, have been subjected to heavy precipitation of $\mathrm{Cr}$ carbides. In addition, a relatively precipitate-free zone (PFZ) $(125 \mu \mathrm{m})$ exists at the interface with the coating. The PFZ could be due to diffusional depletion of $\mathrm{Cr}$ in this region. A thin layer of fine recrystallized grains $(35 \mu \mathrm{m})$ exists at the coating interface. It is likely that a deformed substrate surface before coating was recrystallized during coating.
The pre-oxidation processing has left the stainless-steel substrates in a condition that, if exposed to aqueous acid solutions, will likely produce intergranular corrosion. This type of localized corrosion of sensitized alloys in molten salts has not been reported. Because of this lack of information, more evaluations will be required if these alloys are employed in high-temperature molten-salt CSP applications in the temperature range of $700-900^{\circ} \mathrm{C}$.

Metallographic characterization of HVOF-NiCoCrAlYTa coating on $310 \mathrm{SS}$ substrate pre-oxidized (air, $900^{\circ} \mathrm{C}, 24 \mathrm{~h}, 0.5^{\circ} \mathrm{C} / \mathrm{min}$ ) and corrosion tested in $\mathrm{NaCl}-\mathrm{KCl}$ at $700^{\circ} \mathrm{C}$ in $\mathrm{N}_{2}(\mathrm{~g})$ atmosphere is reported in Figs. 3 and 4 . The microstructure at the coating/steel interface is shown in Fig. 3. Small precipitates $(1-2 \mu \mathrm{m})$ in the stainless steel were found to be $\mathrm{Cr}$-rich carbides or oxycarbides. In the stainless steel, a PFZ near the interface was identified that could be derived from depletion of $\mathrm{Cr}$ due to sensitization during pre-oxidation or interaction with the coating during deposition. It could also be associated with formation of the layer of recrystallization and grain growth described above. Many of the dark particles at the interface, as observed previously, are Al-rich oxides or oxynitrides. The dark layer at the coating/steel interface has formed in association with grain-boundary penetrations of the 31055 substrate, indicative of interaction between coating and substrate during deposition. The dark layer was found to be a $\mathrm{Cr}$ rich oxide phase. To form this phase, $\mathrm{Cr}$ could have been supplied by the coating, the substrate, or both. The PFZ in the steel indicates that $\mathrm{Cr}$ would likely have been supplied, at least in part, by the steel. Thus, Cr-rich oxide phases have formed at the coating/steel interface.

At the top or outer surface of the pre-oxidized and corroded coating, a dark phase is frequently observed to form in association with the wavy oxide scale of the coating microstructure, as if some type of corrosion occurred along the oxide scale. Penetration of a dark-contrasted constituent into the outer surface of the coating was resolved by BSE-SEM/EDS (Fig. 4). The dark phase or constituent has penetrated the surface along the interfaces of the wavy oxide scales of the coating, frequently in association with porosity formation. The coarse dark penetrating phase is a $\mathrm{Cr}$-rich oxide phase that possibly contains yttrium. A discontinuous, granular, and apparently friable surface deposit exists on the coating surface. EDS analyses (labeled a, b, and c in Fig. 4) indicate a mixture of Al-rich, $\mathrm{Cr}$-rich, and possibly Y-rich oxide phases in the surface deposit. Chromium in the coating appears to have been preferentially oxidized.

The top-surface microstructure of the pre-oxidized and moltensalt-exposed NiCoCrAlYTa coating corroborates the low corrosion rate of $190 \mu \mathrm{m} / \mathrm{yr}$ obtained and indicates protection of the coating from $\mathrm{NaCl}-\mathrm{KCl}$ molten-salt corrosion. EDS analysis (Supplementary Table 2) indicates a mixture of Al-rich, $\mathrm{Cr}$-rich, and possibly Y-rich oxide phases in the surface deposit.

Metallographic characterization of as-deposited HVOF-Amdry 510 ( $\mathrm{NiCrAl}$ ) tested with two consecutive polarizations in $\mathrm{NaCl}-\mathrm{KCl}$ at $700^{\circ} \mathrm{C}$ in $\mathrm{N}_{2}(\mathrm{~g})$ atmosphere is shown in Fig. 5 and Supplementary Figs. 7 and 8. This sample showed passivation behavior during anodic polarization and subsequent decrease in its corrosion rate from $3340 \mu \mathrm{m} / \mathrm{yr}$ to $590 \mu \mathrm{m} / \mathrm{yr}$ (see Table 1 and Supplementary Fig. 1). A good coating adhesion to the substrate was observed in this sample with no observable fissures. The coating microstructure resolved the evolution of a coarse phase at the dark wavy droplet oxide scales (see Supplementary Fig. 7). The overall EDS chemical composition of the coating was confirmed as essentially NiCrAl. Nitrogen was detected in some dark phases. The coarse gray phase at the wavy dark features was determined to be a Cr-rich oxide or oxynitride. Oxynitrides, if present, are believed to be formed during the coating deposition process because it was performed at room atmosphere. The light matrix immediately adjacent to the coarse wavy phase is poorer in Al and $\mathrm{Cr}$, with low to no $\mathrm{O}$. The dark wavy constituent, as before, appears 


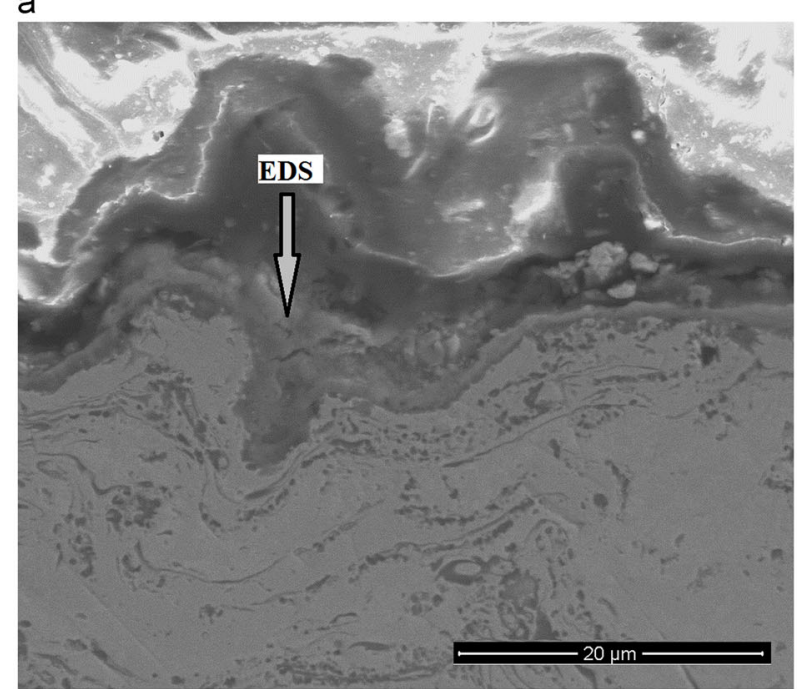

b

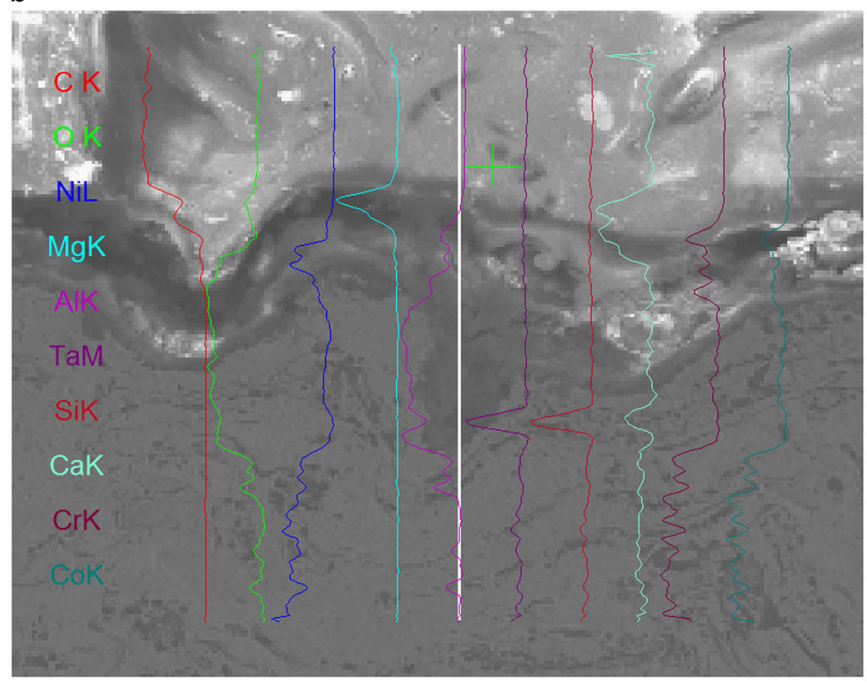

$\mathrm{C}$
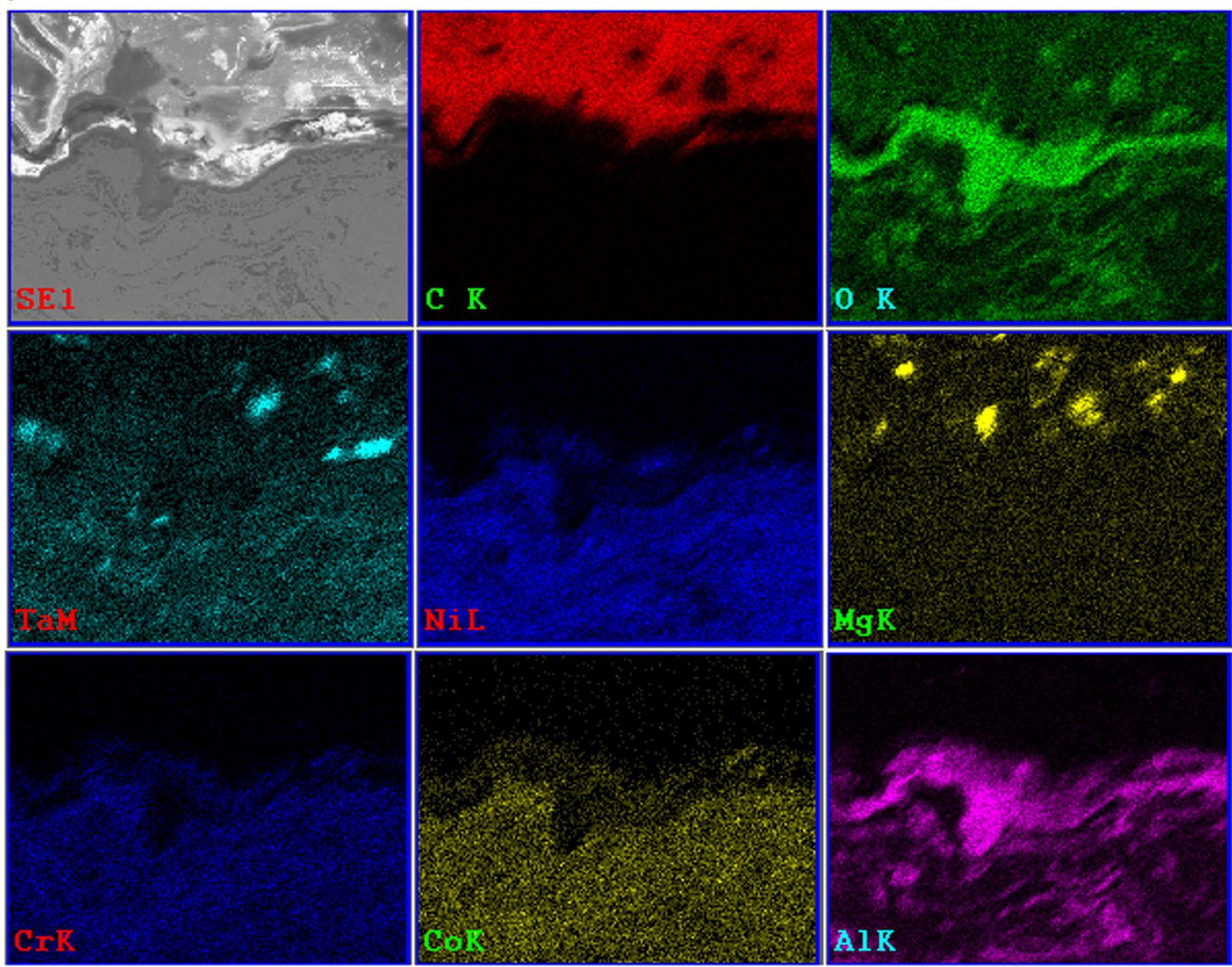

Fig. 2 BSE-FESEM/EDS of cross-section surface of oxidized HVOF-NiCoCrAlYTa (air, $900{ }^{\circ} \mathrm{C}, 24 \mathrm{~h}, 0.5^{\circ} \mathrm{C} / \mathrm{min}$ ): a Top oxidized surface showing oxide phases EDS of uniform top layer (semi-quantitative composition in wt\%: 1.38 C, 22.40 O, 23.97 Al, $1.46 \mathrm{Si}, 20.83 \mathrm{Cr}, 0.54 \mathrm{Fe}, 11.32 \mathrm{Co}$, $18.10 \mathrm{Ni}$ ), b EDS line scan (white line) across gray layer showing presence of mostly aluminum oxide with no chromium or nickel oxides forming, and c EDS maps showing that dense, continuous, and uniform alumina is the only oxide forming at the surface. Scale bar is $20 \mu \mathrm{m}$ 


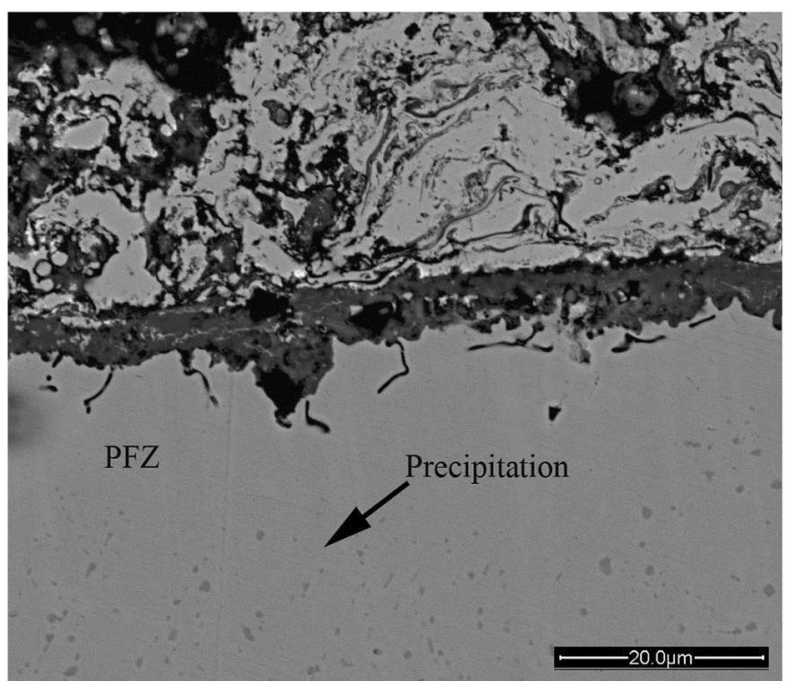

Fig. 3 BSE-SEM image of HVOF-NiCoCrAIYTa pre-oxidized (air, $900^{\circ} \mathrm{C}$, $24 \mathrm{~h}, 0.5^{\circ} \mathrm{C} / \mathrm{min}$ ) and exposed to $\mathrm{NaCl}-\mathrm{KCl}$ at $700^{\circ} \mathrm{C}$ showing microstructure at coating/steel interface. Dark gray layer is Al-rich and $\mathrm{Cr}$-rich oxide phases. PFZ: precipitate-free zone. Scale bar is $20 \mu \mathrm{m}$

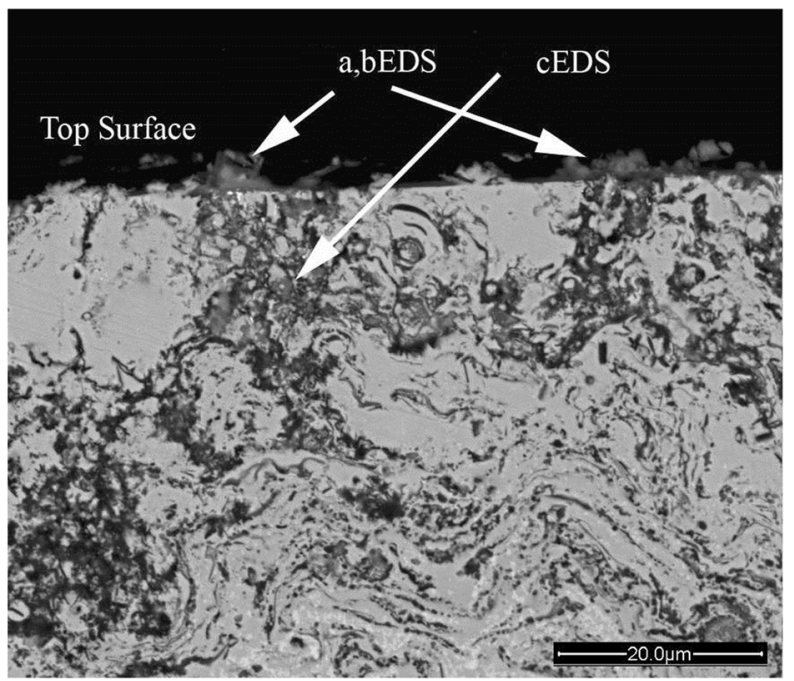

Fig. 4 BSE-SEM image of HVOF-NiCoCrAlYTa pre-oxidized (air, $900^{\circ} \mathrm{C}$, $24 \mathrm{~h}, 0.5^{\circ} \mathrm{C} / \mathrm{min}$ ) and exposed to $\mathrm{NaCl}-\mathrm{KCl}$ at $700^{\circ} \mathrm{C}$ showing penetration at the outer surface of the top coating. Scale bar is 20 $\mu \mathrm{m}$

to be an Al-rich $\mathrm{Al}-\mathrm{Cr}-\mathrm{O}$ phase. Thus, the coarse gray phase appears to have developed in association with the dark wavy droplet oxide scale. At the top surface coating, where the specimen has been exposed to $\mathrm{NaCl}-\mathrm{KCl}$ molten salt, a dispersion of fine darker features is observed (Fig. 5). The interface of the well-adhered top coating is characterized by gentle interface undulation, coarse particles, and thin interface phases.

The partially spalled surface scale comprises a mixture of $\mathrm{NaCl}$ and $\mathrm{KCl}$. In addition, where the underlying coating is visible, a dispersion of fine dark features is observable. The dispersion of fine features exists in a layer 20 to $50 \mu \mathrm{m}$ deep. The dispersion of fine features extends to a fairly definite depth from the surface (see Supplementary Figure 8) and appears to be associated with the dark wavy oxide scale constituent. The coating beneath the layer of the dispersion is relatively free of fine features. Although it was not possible to resolve the chemical composition of individual

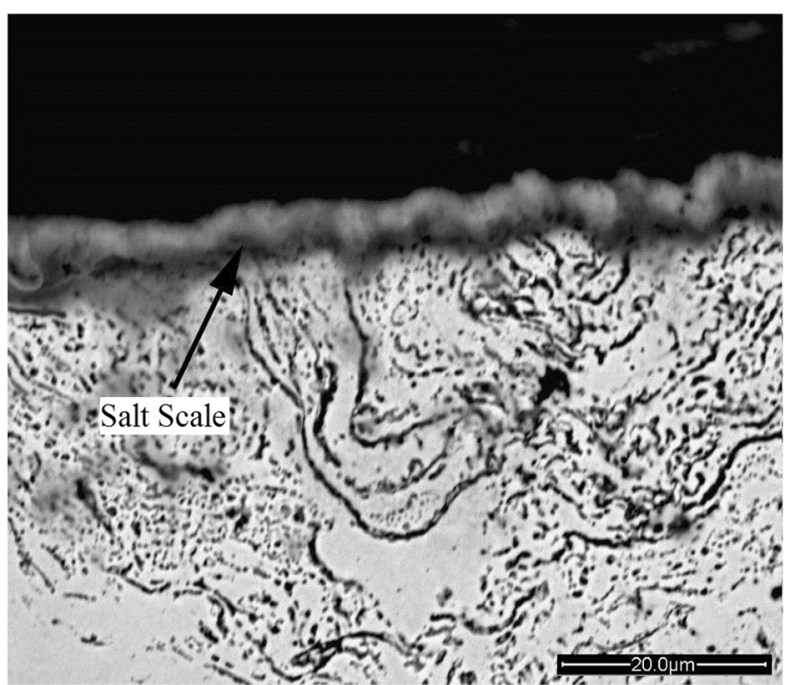

Fig. 5 BSE-SEM image of top surface of as-deposited HVOF-NiCrAl tested with two consecutive polarizations in $\mathrm{NaCl}-\mathrm{KCl}$ at $700^{\circ} \mathrm{C}$ in $\mathrm{N}_{2}(\mathrm{~g})$ atmosphere showing salt scale. Scale bar is $20 \mu \mathrm{m}$

features, EDS chemical analyses of the region of dispersion compared to deeper regions free of the dispersion features indicated elevated levels of $\mathrm{Cr}$ and relatively lower levels of $\mathrm{Al}$ compared to the overall chemical composition of the coating. It would then appear that the chloride molten-salt degradation of the HVOF-NiCrAl coating is associated with formation of a $50-\mu \mathrm{m}-$ thick layer that contains a dispersion of fine dark features. The layer is elevated in $\mathrm{Cr}$, probably due to the formation of a $\mathrm{Cr}$-rich oxide. If the dispersion of features is associated with a fine-scale porosity, this assumption would be consistent with a mechanism for molten-salt corrosion proposed by others. That mechanism proposes preferential oxidation of $\mathrm{Cr}$ by the chloride molten salt and literal fluxing or de-alloying of the $\mathrm{Cr}$. A by-product of such a mechanism is an inward flux of vacancies and formation of porosity. ${ }^{12,13}$

Corrosion of alloys in molten chlorides from 650 to $700{ }^{\circ} \mathrm{C}$ in a nitrogen atmosphere has been reported to be very aggressive. ${ }^{3-7,9}$ Alloys $310 \mathrm{SS}$ and In800H exhibited localized corrosion in molten eutectic $\mathrm{NaCl}-\mathrm{LiCl}$. Inconel 625 was the most corrosion-resistant alloy with a corrosion rate of $2800 \pm 380 \mu \mathrm{m} / \mathrm{yr}$. For CSP applications, corrosion rates with these magnitudes are not acceptable because of economic considerations. Additionally, localized corrosion (intergranular or pitting) can be catastrophic.

Approaches to mitigate corrosion are required for advanced high-temperature CSP plants to be commercially viable. The present study investigated the effect of $\mathrm{Ni}$-based coatings to protect the alloys from corrosion in molten chloride. Based on the corrosion rates reported here, we determined that pre-oxidation of aluminum-containing coatings is a good surface treatment as a corrosion-mitigation approach because it allows the formation of protective alumina scales that decrease corrosion 24 times-from $\mathrm{mm} / \mathrm{yr}$ of scale to a few hundred $\mu \mathrm{m} / \mathrm{yr}$.

Bare $310 \mathrm{SS}$ and In800H alloys corroded in molten $44.53 \mathrm{wt} \%$ $\mathrm{NaCl}-55.47 \mathrm{wt} \% \mathrm{KCl}$ at $700^{\circ} \mathrm{C}$ in a $\mathrm{N}_{2}(\mathrm{~g})$ atmosphere at very high corrosion rates of $\sim 4500$ and $\sim 2500 \mu \mathrm{m} / \mathrm{yr}$, respectively. All the thermal deposited coatings passed the qualitative adhesion test, with no coating removal from the surface. Coated alloys reported lower corrosion rates, showing that they could contribute to mitigate corrosion of alloys in molten chlorides for the timescales studied. Long-term studies and durability will remain an important challenge for the energy industry.

All the selected coatings were deposited using HVOF and APS. These coatings were corrosion tested in the electrochemical cell in 
the as-deposited and pre-oxidation conditions. All the asdeposited coatings, except $\mathrm{NiCrAl}$, showed a reduction in the corrosion rate $(570 \mu \mathrm{m} / \mathrm{yr}$ for NiCoCrAIYTa, $980 \mu \mathrm{m} / \mathrm{yr}$ for NiCoCrAIYHfSi, $1230 \mu \mathrm{m} / \mathrm{yr}$ for NiCoCrAlY, and $1240 \mu \mathrm{m} / \mathrm{yr}$ for NiAl). The corrosion rate reduction could be associated with the higher $\mathrm{Ni}$ concentration in the coatings compared with the substrate alloys. Because $\mathrm{Ni}$ is more stable than $\mathrm{Cr}$ and $\mathrm{Fe}$ in molten chlorides, the coatings provided a certain degree of protection, but not enough for CSP applications.

The best coating was HVOF-NiCoCrAIYTa pre-oxidized in air at $900^{\circ} \mathrm{C}$ for $24 \mathrm{~h}$ with heating/cooling rates of $0.5^{\circ} \mathrm{C} / \mathrm{min}$. At this pre-oxidation condition, the coating showed a corrosion rate of $190 \mu \mathrm{m} / \mathrm{yr}$. After oxidation, the formation of a uniform and dense layer consisting of mostly alumina was resolved by SEM/EDS. Chromium and aluminum in the coating were preferentially oxidized during pre-oxidation. This oxide layer could help increase the corrosion resistance of the coatings. Alumina is a protective oxide with few defects in its structure, which minimizes or avoids the diffusion of elements; thus, corrosion is controlled or mitigated. The surface characterization of the pre-oxidized NiCoCrAIYTa exposed to the molten chloride indicates that the treated coating was more resistant to chloride molten-salt corrosion. Metallographic characterization of molten-salt tested samples resolved the remaining presence of Al-rich, $\mathrm{Cr}$-rich, and $\mathrm{Y}$ rich oxide phases in the top surface.

The electroetched substrate (310SS and In $800 \mathrm{H}$ ) in the asdeposited coated sample resolved the presence of chromium carbide precipitates at the grain boundaries and in the bulk of the grains. These precipitates are characteristics of a sensitized alloy in which precipitation of $\mathrm{Cr}$-rich carbide depleted the steel matrix locally in $\mathrm{Cr}$. Sensitization occurs with relatively high $\mathrm{C}$ levels in the steel and sufficient time in the temperature range of $700-900^{\circ} \mathrm{C}$. The same effect will be obtained with slow cooling in the same temperature range. The sensitization of the as-deposited sample could occur during the spray deposition process. The molten particles impacting the surface of the substrate increase the surface temperature locally, increasing the feasibility of carbide precipitation. This effect is observed in the heat-affected zone during welding processes. After pre-oxidation, the amount of $\mathrm{Cr}$ carbide particles in the substrate increased the depletion of $\mathrm{Cr}$ in the matrix even more.

It has been reported that sensitization makes the alloy prone to intergranular corrosion if exposed to chloride aqueous solutions. No information is available for molten chloride corrosion of sensitized alloys, so surface protection of alloys exposed to molten chlorides is imperative. If it is determined that molten chlorides can corrode sensitized alloys, increasing the corrosion rate, then rapid and unexpected catastrophic failure of the component might occur. Because of this, further studies should be done on alloys $310 \mathrm{SS}$ and $\ln 800 \mathrm{H}$ if their use is considered for hightemperature application in the range of $700-900^{\circ} \mathrm{C}$. If intergranular corrosion is present in the sensitized condition, then the use of these alloys must be avoided in molten chloride environments.

\section{METHODS}

\section{Preparation of salt mixture}

The eutectic 44.53 wt $\% \mathrm{NaCl}-55.47$ wt $\% \mathrm{KCl}$ with a congruent melting point of $657^{\circ} \mathrm{C}$ was selected because it has a high heat of fusion of $417 \mathrm{~J} / \mathrm{kg}$ and a low cost of $\$ 2 / \mathrm{kWh}_{\mathrm{th}}$. These characteristics make this mixture a good phase-change material candidate for latent thermal energy storage systems considered for high-temperature solar thermal applications.

The salt mixture components, $\mathrm{NaCl}$ and $\mathrm{KCl}$, each with a purity greater than $99 \mathrm{wt} \%$, were acquired from Alfa Aesar. To ensure low-moisture content, the salts were kept in a drying oven (DK-42, American Scientific Products) at $120^{\circ} \mathrm{C}$ in air for at least $24 \mathrm{~h}$. The dried salts were weighed and mixed to the proper ratio in 125-g batches in a glove box under dry nitrogen. The salts were then placed in an alumina crucible because this material has been shown to be stable in chloride molten-salt systems. ${ }^{3-5,8,9}$
The crucible containing the salt mixture was kept in a vacuum furnace at $120^{\circ} \mathrm{C}$ for $24 \mathrm{~h}$ and then transferred to a muffle furnace (Vulcan 3-1750), where it was heated and held at $300^{\circ} \mathrm{C}$ for $3 \mathrm{~h}$. The temperature was then raised to $850^{\circ} \mathrm{C}$, where it was maintained for $30 \mathrm{~min}$ to completely melt the components. To avoid moisture absorption after cooling, the premelted and solidified salt mixture was stored at $120^{\circ} \mathrm{C}$ in the drying oven until needed for testing. CSP plants cannot pursue very complicated and expensive mixing and melting procedures of the salts, so the salt preparation followed here did not consider any further purification of the mixture.

\section{Preparation of alloys and coatings}

The nominal composition of substrate alloys and coatings tested are shown in Supplementary Tables 3 and 4 . Alloys $\operatorname{In} 800 \mathrm{H}$ and $310 \mathrm{SS}$ were machined to $8 \mathrm{~mm}$ in diameter and $12 \mathrm{~mm}$ in height. High-velocity oxyfuel (HVOF) and atmospheric thermal plasma spray (APS) technologies were employed for the coating deposition. Coating deposition was setup to have thicknesses $\sim 1 \mathrm{~mm}$ for the corrosion electrochemical tests. These coatings need to be ground and polished to very flat surfaces to use the geometrical area to normalize the corrosion current and thus determine the chemical performance of the coating material. Bare and coated alloys were progressively polished using up to a 1200-grit SiC abrasive paper, cleaned with deionized (DI) water, and dried with acetone and compressed air. Polishing is required before electrochemical corrosion tests to control the amount of area exposed to the corroding fluid and thus normalize the measured current to obtain the current density. To determine the effect of alumina layers against molten chloride corrosion, some coatings were oxidized in air prior to molten-salt exposure. To establish the electrical connection required for electrochemical testing, nickel-chromium wire (0.5-mm diameter) was welded to the sample. Alumina tubing sealed with refractory cement was employed to insulate the wire. Pre-oxidation of the coatings were performed in atmospheric air at different temperatures and dwelling times using $0.5^{\circ} \mathrm{C} / \mathrm{min}$ as the heating and cooling rates.

\section{Electrochemical corrosion tests}

The electrochemical cell experimental setup used in this work is given elsewhere. ${ }^{3-5,8,9}$ A crucible electrical resistance furnace was used to contain the cell made of $316 \mathrm{~L}$. The electrochemical cell contains a quartz liner and an off-gas treatment to trap the chloride by-products. A threeelectrode arrangement was used with the working electrode (WE) as the sample to be tested. The pseudo reference electrode (RE) was made from 0.5-mm-diameter Pt wire, and the counter electrode (CE) was Pt-gauge spot welded to $0.5-\mathrm{mm}$-diameter $\mathrm{Pt}$ wire. The couple pseudo-PtRE/PtCE electrical stability in molten chloride salts has been reported in previous work to be reached after around $45 \min ^{3,9,12}$

The corrosion evaluations were performed at $700^{\circ} \mathrm{C}$ in a nitrogen atmosphere using a potentiostat (AUTOLAB-PGSTAT302N). A type-K thermocouple in an alumina well was used near the electrodes to record the temperature test. The electrochemical cell setup was sealed and purged with nitrogen for about $24 \mathrm{~h}$ before the corrosion testing. The offgas passed through a series of traps to remove hazardous chlorine vapors before being vented to local exhaust. After reaching thermal equilibration (about $1 \mathrm{~h}$ ) at $700{ }^{\circ} \mathrm{C}$, the pseudo-PtRE and the PtCE were immersed into the molten chloride salt and allowed to stabilize for about 45-60 min.

To determine the near-steady OCP, potential was continuously recorded starting immediately after its immersion in the molten chloride until a constant potential $(\mathrm{dE} / \mathrm{dt} \leq 100 \mu \mathrm{V} / \mathrm{s})$ was obtained. Potentiodynamic polarization studies were conducted immediately after by applying cathodic and anodic external potentials starting with cathodic polarization at $0.001-\mathrm{V}$ steps and $0.001 \mathrm{~V} / \mathrm{s}$. Cathodic overpotentials were limited to only $-0.35 \mathrm{~V}$ below the OCP to avoid surface modifications of the sample during cathodic polarization due to reduction of impurities over the surface. Anodic polarization was performed up to $+0.6 \mathrm{~V}$ above the OCP to determine if the sample is capable of passivation. More than three coupons per test were performed under the same conditions to evaluate the reproducibility of the results. The corrosion rate was calculated using Eq. 1 with $i_{\text {corr }}$ determined from the intersection of the extrapolated straight sections of the cathodic and anodic Tafel lines within an interval of $250 \mathrm{mV}$ with respect to OCP (or $E_{\text {corr }}$ ).

\section{Sample characterization}

As-deposited, pre-oxidized, and corroded coated samples were metallographically characterized. The sample preparation for these analyses was 
performed by encapsulating the samples in bakelite for cross-section analyses. For this, the encapsulated samples were progressively polished using up to a 1200-grit SiC abrasive paper followed by $6-\mu \mathrm{m}, 1-\mu \mathrm{m}$, and $0.1-\mu \mathrm{m}$ diamond lapping. Lapping was performed on low-nap polishing cloths, at low speed for short time, to prevent edge rounding at the outer surface of the coating. After polishing, the samples were cleaned with DI water, and dried with acetone and compressed air. The specimens were initially prepared for observation in an unetched condition. Subsequently, they were electroetched in an aqueous $10 \%$ oxalic acid electrolyte to characterize the microstructure of the stainless-steel substrate. It should be noted that oxalic acid electroetching represents a test for sensitization of stainless steels, described in ASTM B162. Sensitization represents a corrosion-prone condition in which $\mathrm{Cr}$-rich carbides precipitate at microstructural features such as grain boundaries.

Cross-sectioned and polished samples were metallographically characterized using LM and environmental scanning electron microscopy (ESEM). Secondary electron and backscattered electron (BSE) imaging was accomplished. Regions of relatively light contrast in BSE images are associated with elements having relatively lower atomic weight. Localized semi-quantitative chemical analysis was accomplished in conjunction with SEM via energy-dispersive X-ray spectrometry (EDS). Semi-quantitative EDS analyses were performed, resulting in low accuracy for elements of low atomic number such as $\mathrm{C}, \mathrm{N}$, and $\mathrm{O}$.

After the corrosion test, samples were removed from the corrosion cell and cleaned in warm DI water to dissolve solidified salt from the surface. After salt removal, the samples were cleaned with acetone and kept in the drying furnace before encapsulation in bakelite for cross-section analysis.

\section{Data availability}

The data sets generated during and/or analyzed during the current study are available from the corresponding author on reasonable request.

\section{ACKNOWLEDGEMENTS}

The work at NREL was supported financially by the U.S. Department of Energy under Contract No. DE-AC36-08-GO28308.

\section{AUTHOR CONTRIBUTIONS}

Dr. J.C.G.-V., as the sole author and contributor of the paper, was the principal investigator of the project. She was responsible for the sample preparation, corrosion tests setup, testing, measurement of electrochemical variables, analysis of the data, characterization and analysis of the results.

\section{ADDITIONAL INFORMATION}

Supplementary Information accompanies the paper on the npj Materials Degradation website (doi:10.1038/s41529-017-0012-3).

Competing interests: The author declares no competing financial interests.

Publisher's note: Springer Nature remains neutral with regard to jurisdictional claims in published maps and institutional affiliations.

\section{REFERENCES}

1. Mehos, M. et al. Concentrating solar power Gen3 demonstration roadmap. Technical Report NREL/TP-5500-67464 (2017).

2. Vignarooban, K., Xu, X., Arvay, A., Hsu, K. \& Kannan, A. M. Heat transfer fluids for concentrating solar power systems - A review. Appl. Energ. 146, 383-396 (2015).

3. Gomez-Vidal, J. C. \& Tirawat, R. Corrosion of alloys in a chloride molten salt (NaCl-LiCl) for solar thermal technologies. Sol. Energ. Mat. Sol. C 157, 234-244 (2016).

4. Gomez-Vidal, J. C., Fernandez, A. G., Tirawat, R., Turchi, C. \& Huddleston, W. Corrosion resistance of alumina forming alloys against molten chlorides for energy production. I: pre-oxidation treatment and isothermal corrosion tests. Sol. Energ. Mat. Sol. C 166, 222-233 (2017).

5. Gomez-Vidal, J. C., Fernandez, A. G., Tirawat, R., Turchi, C. \& Huddleston, W. Corrosion resistance of alumina forming alloys against molten chlorides for energy production. II: Electrochemical impedance spectroscopy under thermal cycling conditions. Sol. Energ. Mat. Sol. C 166, 234-245 (2017).

6. Vignarooban, K., Pugazhendhi, P., Tucker, C., Gervasio, D. \& Kannan, A. M. Corrosion resistance of Hastelloys in molten metal-chloride heat-transfer fluids for concentrating solar power applications. Sol. Energy 103, 62-69 (2014).
7. Kruizenga, A.M. Corrosion mechanisms in chloride and carbonate salts. Sandia Report SAND2012-7594 (2012).

8. Gomez-Vidal, J. C., Noel, J. \& Weber, J. Corrosion evaluation of alloys and MCrAIX coatings in molten carbonates for thermal solar applications. Sol. Energ. Mat. Sol. C 157, 517-525 (2016).

9. Gomez-Vidal, J. C. \& Morton, E. Castable cements to prevent corrosion of metals in molten salts. Sol. Energ. Mat. Sol. C 153, 44-51 (2016).

10. Groll, M., Brost, O. \& Heine, D. Corrosion of steels in contact with salt eutectics as latent heat storage materials: Influence of water and other impurities. Heat. Recov. Syst. 10, 567-572 (1990).

11. Cuevas-Arteaga, C., Uruchurtu-Chavarin, J., Porcayo-Calderon, J., Izquierdo-Montalvo, G. \& Gonzalez, J. Study of molten salt corrosion of HK-40m alloy applying linear polarization resistance and conventional weight loss techniques. Corros. Sci. 46, 2663-2679 (2004).

12. Porcayo-Calderon, J. et al. Electrochemical performance of $\mathrm{Ni} 20 \mathrm{Cr}$ coatings applied by combustion powder spray in $\mathrm{ZnCl}_{2}-\mathrm{KCl}$ molten salts. Int. J. Electrochem. Sci. 7, 1134-1148 (2012).

13. Li, Y. S., Spiegel, M. \& Shimad, S. Corrosion behaviour of various model alloys with $\mathrm{NaCl}-\mathrm{KCl}$ coating. Mater. Chem. Phys. 93, 217-223 (2005).

14. Gurrappa, I. Identification of hot corrosion resistant MCrAlY based bond coatings for gas turbine engine applications. Surf. Coat. Technol. 139, 272-283 (2001).

15. Gurrappa, I. \& Sambasiva-Rao, A. Thermal barrier coatings for enhanced efficiency of gas turbine engines. Surf. Coat. Technol. 201, 3016-3029 (2006).

16. Jiang, S. M. et al. Preparation and hot corrosion behavior of a MCrAlY + AISiY composite coating. Corros. Sci. 50, 3213-3220 (2008).

17. Jiang, S. M. et al. High temperature corrosion behaviour of a gradient NiCoCrAlYSi coating. I: microstructure evolution. Corros. Sci. 52, 1746-1752 (2010).

18. Jiang, S. M. et al. High temperature corrosion behavior of a gradient NiCoCrAlYSi coating. Il: oxidation and hot corrosion. Corros. Sci. 52, 2316-2322 (2010).

19. Wang, B., Sun, C., Gong, J., Huang, R. \& Wen, L. Oxidation behaviour of the alloy IC-6 and protective coatings. Corros. Sci. 46, 519-528 (2004).

20. Wang, H. et al. Hot corrosion behavior of low Al NiCoCrAlY cladded coatings reinforced by nano-particles on a Ni-base super alloy. Corros. Sci. 52, 3561-3567 (2010).

21. Zhong, X. H. et al. Hot-corrosion behaviors of overlay-clad yttria-stabilized zirconia coatings in contact with vanadate-sulfate salts. J. Eur. Ceram. Soc. 30, 1401-1408 (2010).

22. Bao, Z. B. et al. Preparation and hot corrosion behaviour of an Al-gradient NiCoCrAIYSiB coating on a Ni-base superalloy. Corros. Sci. 51, 860-867 (2009).

23. Guo, M. H. et al. Oxidation and hot corrosion behavior of gradient NiCoCrAlYSiB coatings deposited by a combination of arc ion plating and magnetron sputtering techniques. Corros. Sci. 48, 2750 (2006).

24. Nicholls, J. R., Simms, N. J., Chan, W. Y. \& Evans, H. E. Smart overlay coatingsconcept and practice. Surf. Coat. Technol. 149, 236 (2002).

25. Ren, X. \& Wang, F. H. High-temperature oxidation and hot-corrosion behavior of a sputtered NiCrAlY coating with and without aluminizing. Surf. Coat. Technol. 201, 30 (2006).

26. Meier, V. \& Pettit, V. High-temperature corrosion of alumina-forming coatings for superalloys. Surf. Coat. Technol. 39/40, 1-17 (1989).

27. Singh, H., Puri, D. \& Prakash, S. Some studies on hot corrosion performance of plasma sprayed coatings on a Fe-based superalloy. Surf. Coat. Technol. 192, 27-38 (2005).

28. Ma, J., Jiang, S. M., Gong, J. \& Sun, C. Behavior and mechanisms of alkali-sulfateinduced hot corrosion on composite coatings at $900^{\circ}$ C. Corros. Sci. 58, 251-259 (2012).

29. Wang, H., Zuo, D. W., Sun, Y. L., Xu, F. \& Zhang, D. Microstructure of nanometer $\mathrm{Al}_{2} \mathrm{O}_{3}$ dispersion strengthened $\mathrm{Ni}$-based high-temperature protective coatings by laser cladding. T. Nonferr. Metal. Soc. 19, 586-591 (2009).

30. Fritscher, K., Leyens, C. \& Peters, M. Development of a low-expansion bond coating for Ni-base superalloys. Mater. Sci. Eng.: A 190, 253-258 (1995).

31. Clarke, D. R. \& Levi, C. G. Materials design for the next generation thermal barrier coatings. Annu. Rev. Mater. Res. 33, 383-417 (2003).

32. Tristancho-Reyes, J. L. Hot corrosion behavior of NiCrFeNbMoTiAl coating in molten salts at $700^{\circ} \mathrm{C}$ by electrochemical techniques. Int. J. Electrochem. Sci. 6, 432-441 (2011).

33. Huang, X. Developing corrosion prevention coating solutions for the Canadian SCWR Concept. JOM 68, 480-484 (2016).

34. Guo, H., Li, D., Peng, H., Cui, Y. \& Gong, S. High-temperature oxidation and hotcorrosion behaviour of EB-PVD $\beta$-NiAIDy coatings. Corros. Sci. 53, 1050-1059 (2011).

35. Eriksson, R., Yuan, K., Li, X.-H. \& Lin Peng, R. MCrAlY coating design based on oxidation-diffusion modelling. Part II: lifing aspects. Surf. Coat. Technol. 253, 27-37 (2014)

36. Brady, M. P., Smialek, J. L., Smith, J. \& Humphrey, D. L. The role of $\mathrm{Cr}$ in promoting protective alumina scale formation by $\mathrm{\gamma}$-based $\mathrm{Ti}-\mathrm{Al}-\mathrm{Cr}$ alloys. I. Compatibility 
with alumina and oxidation behavior in oxygen. Acta Mater. 45, 2357-2369 (1997).

37. Jeurgens, L. P. H., Sloof, W. G., Tichelaar, F. D. \& Mittemeijer, E. J. Structure and morphology of aluminium-oxide films formed by thermal oxidation of aluminium. Thin Solid Films 418, 89-101 (2002).

38. Jeurgens, L. P. H., Sloof, W. G., Tichelaar, F. D. \& Mittemeijer, E. J. Growth kinetics and mechanisms of aluminum-oxide films formed by thermal oxidation of aluminum. J. Appl. Phys. 92, 1649-1656 (2002).

39. Jeurgens, L. P. H., Sloof, W. G., Tichelaar, F. D. \& Mittemeijer, E. J. Composition and chemical state of the ions of aluminium-oxide films formed by thermal oxidation of aluminium. Surf. Sci. 506, 313-332 (2002).

40. Huntz, A. M., Hou, P. Y. \& Molins, R. Study by deflection of the oxygen pressure influence on the phase transformation in alumina thin films formed by oxidation of $\mathrm{Fe}_{3} \mathrm{Al}$. Mater. Sci. Eng.: A 467, 59-70 (2007).

41. Levin, I. \& Brandon, D. Metastable alumina polymorphs: Crystal structures and transition sequences. J. Am. Ceram. Soc. 81, 1995-2012 (1998).

42. Espinosa-Medina, M. A. et al. Hot corrosion of atomized iron aluminides doped with boron and reinforced with alumina. Mater. Sci. Eng. A300, 183-189 (2001).

43. Cai, J., Xu, B. \& Ling, G. Observation on the interface of $\mathrm{a}-\mathrm{Al}_{2} \mathrm{O}_{3} / \mathrm{Cr}_{2} \mathrm{O}_{3}$ : Prepared by oxidation of $\mathrm{Al}_{45} \mathrm{Cr}_{7}$. Appl. Surf. Sci. 268, 111-116 (2013).

44. Espinosa-Medina, M. A., Carbajal-De la Torre, G., Liu, H. B., Martínez-Villafañe, A. \& González-Rodriguez, J. G. Hot corrosion behaviour of Fe-Al based intermetallic in molten $\mathrm{NaVO}_{3}$ salt. Corros. Sci. 51, 1420-1427 (2009).

45. Rapp, R. A. \& Zhang, Y. S. Hot corrosion of materials: Fundamental studies. JOM 46, 47-55 (1994).

46. Gamry Instruments, Getting started with electrochemical corrosion measurements (2011)
47. Gonzalez-Rodriguez, J. G. et al. An electrochemical study of the effect of Li on the corrosion behavior of $\mathrm{Ni}_{3} \mathrm{Al}$ intermetallic alloy in molten $(\mathrm{Li}+\mathrm{K})$ carbonate. Corros. Sci. 51, 1619-1627 (2009).

48. Bolelli, G. et al. Wear and impact behaviour of high velocity air-fuel sprayed Fe-Cr-Ni-B-C alloy coatings. Tribol. Int. 95, 372-390 (2016).

49. Stratulat, A., Duff, J. A. \& Marrow, T. J. Grain boundary structure and intergranular stress corrosion crack initiation in high temperature water of a thermally sensitised austenitic stainless steel, observed in situ. Corros. Sci. 85, 428-435 (2014).

50. Zhang, S., Shibata, T. \& Haruna, T. Inhibition effect of metal cations to intergranular stress corrosion cracking of sensitized Type 304 stainless steel. Corros. Sci. 47, 1049-1061 (2005).

(i) Open Access This article is licensed under a Creative Commons Attribution 4.0 International License, which permits use, sharing, adaptation, distribution and reproduction in any medium or format, as long as you give appropriate credit to the original author(s) and the source, provide a link to the Creative Commons license, and indicate if changes were made. The images or other third party material in this article are included in the article's Creative Commons license, unless indicated otherwise in a credit line to the material. If material is not included in the article's Creative Commons license and your intended use is not permitted by statutory regulation or exceeds the permitted use, you will need to obtain permission directly from the copyright holder. To view a copy of this license, visit http://creativecommons. org/licenses/by/4.0/.

(c) The Author(s) 2017 